\title{
Green Infrastructure as a Solution to Hydrological Problems: Bioswales and Created Wetlands
}

\author{
Jerry Lee \\ University of Florida
}

Faculty mentor: Vandana Baweja, College of Design, Construction, and Planning

\begin{abstract}
This paper has shown that green infrastructure is effective in mitigating the harmful effects that urbanization brings to the water cycle. Two green infrastructure strategies - bioswales and created wetlands - are crucial in solving some of the water problems that increasing urbanization has created. Bioswales are engineered green spaces that collect runoff and remove harmful pollutants from the stormwater before it is discharged into surface water sources. Besides polluted stormwater, the other major water problem is eutrophication. Created wetlands are effective ecological tools for mitigating eutrophication, which is the result of excessive nutrients in water bodies that cause algal blooms and subsequently suffocate other organisms in the water by depleting oxygen. By analyzing two case studies, namely the New York City "Rain Gardens" and Freedom Park, a created wetlands in Naples, Florida, it can be concluded that green infrastructure is an effective way to reduce harmful effects of human development. Some examples of mitigated environmental degradation are the reduction of rainwater runoff, reducing of polluting particulate matter within the runoff, improvement of air quality, providing for beautification efforts, mitigation of erosion, habitat loss, and prevention of eutrophication
\end{abstract}

Keywords: created wetlands, bioswales, green infrastructure, watershed protection

\section{Introduction}

Green infrastructure is an ecological landscaping method that was first theorized in a 1994 Floridian report titled Creating a Statewide Greenways System, which was presented to the governor at the time, Lawton Chiles (Florida Greenways Commission, MacKay, \& Reed 1994). As defined by the European Commission, green infrastructure is "a strategically planned network of natural and semi-natural areas with other environmental features designed and managed to deliver a wide range of ecosystem services" (Communication from The Commission to The European Parliament, 2013, p. 3). This term began to be used in reference to preservation of the state's fragile ecosystems and mitigate the harmful impact of anthropogenic processes on the state's natural resources. The purpose of this paper is to bring awareness to the harmful effects of anthropogenic development of our time and to suggest ways in which green infrastructure strategies may mitigate the damage humans have done thus far and prevent further environmental damage. To fulfill this purpose, this paper will use case studies to bring attention 
to two of the many green infrastructure strategies and how they may have their respective applications.

\section{Detriments of Current Human Development Habits}

Throughout history there has been an obvious correlation with human development and environmental degradation. With increasing rates of urbanization around the globe, humans are constantly making more and more surface area impermeable. Man-made impervious surfaces force rainwater runoff to rush with a greater force into condensed discharge points into natural bodies of water, rather than a slow diluted penetration into the ground that nature has seen over millennia. Fewer permeable surfaces mean that a higher concentration of urban pollutants is entering natural waterways at fewer points of discharge (Pataki et al., 2011). By destroying natural greenery and foliage with urbanization and not accounting for that loss as cities grow exponentially, humanity exacerbates an already dangerous issue. Increased rates of runoff and pollution in ecosystems surrounding urban settlements means a multitude of problems, some being erosion, eutrophication, habitat loss, and even loss of plant and animal life.

As early as in the 1970s, professor Larry Harris from the University of Florida began to study the fragmentation of wildlife populations in Florida and his efforts led to the Florida Greenways Program, which sought to strategically create a system of greenways, or undeveloped and preserved land, to protect Floridian flora and fauna from the threats of urbanization (Benedict \& McMahon, 2006). His vision was to create a buffer between humanity and wildlife in order to protect nature from the threat of unplanned human expansion.

While urban development and environmental degradation have always come hand in hand, more issues that come with urban development are air quality degradation and the monotony of bland urban infrastructure. Green infrastructure, for example, with its integral use of foliage, assists in the alleviation of air pollution through the natural processes of photosynthesis. In addition, they serve as agents of beautification efforts, bringing much-needed greenery into what may normally be a gray urban landscape.

\section{Green Infrastructure}

Green infrastructure is a landscape strategy that depends on a network of interconnected natural, semi-natural, and manmade entities to provide ecological services that serve the goal of environmental, social, and economic sustainability (Mejía, Shirotova, \& de Almerida, 2015). 
Some notable examples of green infrastructure are, creating oyster reefs for coastal protection, reed beds that treat industrial wastewater, and restoring natural riparian habitat to enhance water provisions (Hawkins \& Pricket, 2014).

Green infrastructure is an idea that has been slowly gaining traction. While the term "green spaces" suggest that greenery is desirable, the term "green infrastructure" is used to imply necessity (Benedict \& McMahon, 2006). Globally, in the last fifty years, urban land that comprise the earth's surface area has quadrupled (Benedict \& McMahon, 2006). As cities increase in size and density, surfaces become less permeable - a stark contrast to naturally occurring terrain untransformed by human settlement. Green infrastructure has therefore become imperative due to increasing urbanization.

\section{Purpose of Green Infrastructure}

As this paper has mentioned previously, Larry Harris's studies began a movement to strategically create a system of greenways to protect wildlife. This effort led to Governor Lawton Chiles's inauguration of the Florida Greenways Commission in 1994, and in 1995 the Florida Department of Environmental Protection contracted the University of Florida to prepare the design of the Floridian greenway system (Benedict \& McMahon, 2006). By September 1998, a system was planned, named the Ecological Network, which to this day protects drinking water, safeguards against flooding and erosion, protects biodiversity, purifies the air, and generates a tourism revenue of about $\$ 3$ billion per year (Benedict \& McMahon, 2006).

Green infrastructure is oftentimes used as a supplement to conventional water management practices, such as gutters, stormwater drains, pipes, and sewers. Green infrastructure can take the form of many different strategies, including bioswales, created wetlands, or a combination of elements, such as a mix of ponds and planted terrain to maintain water quality. One of the most successful examples of green infrastructure are bioswales, which are stormwater infiltration systems. Bioswales are designed to capture stormwater runoff, which is water accumulated through precipitation. The runoff often contains harmful pollutants such as - heavy metals (some being copper, lead, and nickel), agricultural nutrients from lawn fertilizers, pesticides, bacteria, and suspended solids that can contaminate natural water resources (Xiao et al., 2017). Bioswales allow the infiltration of runoff into the ground and mitigate the harmful impacts of runoff on ecosystems (Lovell \& Johnston, 2009). Green infrastructure works by using the landscape and 
ecological processes to store, infiltrate, and evaporate stormwater to relieve pressure on conventional drainage systems (Environmental Protection Agency, 2011).

\section{Bioswales}

Bioswales are defined as low-gradient, open channels possessing covers of vegetation through which surface runoff is directed (Groves et al., 1999). They are designed to move urban runoff away from the built environment. Through their design, bioswales utilize ecological processes, which approximate natural water drainage processes that restore rainwater into the hydrological cycle. In the natural world, plants and soil composition allow a paced penetration of water into the ground. In these green infrastructure areas, the break in concrete and asphalt in the urban landscape allows permeability and the subsequent filtration. This newfound perviousness allows rainwater to soak into the ground, allowing the water to be absorbed and filtered by plants and the soil itself. As the soil and plants soak up the rainwater, they begin to filter out particulate matter such as dissolved metals, nitrates, and phosphates (Soil Science Society of America). Thus, bioswales to some extent restore the natural processes through which water precipitation enters back into surface and groundwater sources, which have since been disrupted due to high levels of urbanization that rendered large tracts of land covered with asphalt and concrete impermeable.

Massive areas of urban surfaces generate large amounts of polluted runoff, which causes water pollution, ecosystem destruction, groundwater recharge deficits, toxicity to aquatic life, and groundwater contamination (Xiao et al., 2017). As bioswales are more pressured than the natural landscape due to the steep ratio of impermeable surface area to soil surface area, bioswales are engineered with soil that allows water infiltration at a fast pace while allowing adequate time for absorption and filtration. In addition, bioswale soil must resist compaction, which would seriously inhibit infiltration rates. Moreover, bioswale soils are required to be able to hold enough water and nutrients to sustain the plant life within it (Soil Science Society of America). Bioswales can be employed to alleviate these issues by providing points of relief within the urban landscape through foliage and greenery.

\section{Construction}

A bioswale is a type of engineered, landscaped, and often modular stormwater collection and management system. Bioswales aim to remove surface runoff as soon as possible, preferably at the source (Xiao et al., 2017). Bioswales are typically gently sloped on the surface or have 
grooves on the side to allow water flow into the vegetated collection area. When water enters the bioswale, the organic material naturally slows the absorption of fluid, preventing harmful effects such as erosion and inefficient filtration that comes from fast water flow (Grenz, 2007). Under the first layer of vegetation and soil, a secondary layer consists of sand, gravel, and/or rock that filters suspended solids from the water before it enters local groundwater systems (Figure 1). As an example of soil engineering, New York City's rain gardens feature two feet of engineered soil and an open-graded stone bed to allow different sizes of particulates to be filtered out (NYC Water Staff, 2017). The finer soil filters out smaller particulates while the larger grade stone bed allows a greater rate of infiltration into the ground. This design can be applied in most urban centers due to the simple but effective concept of soil layers and use of trees to mitigate runoff pollution and pressure.

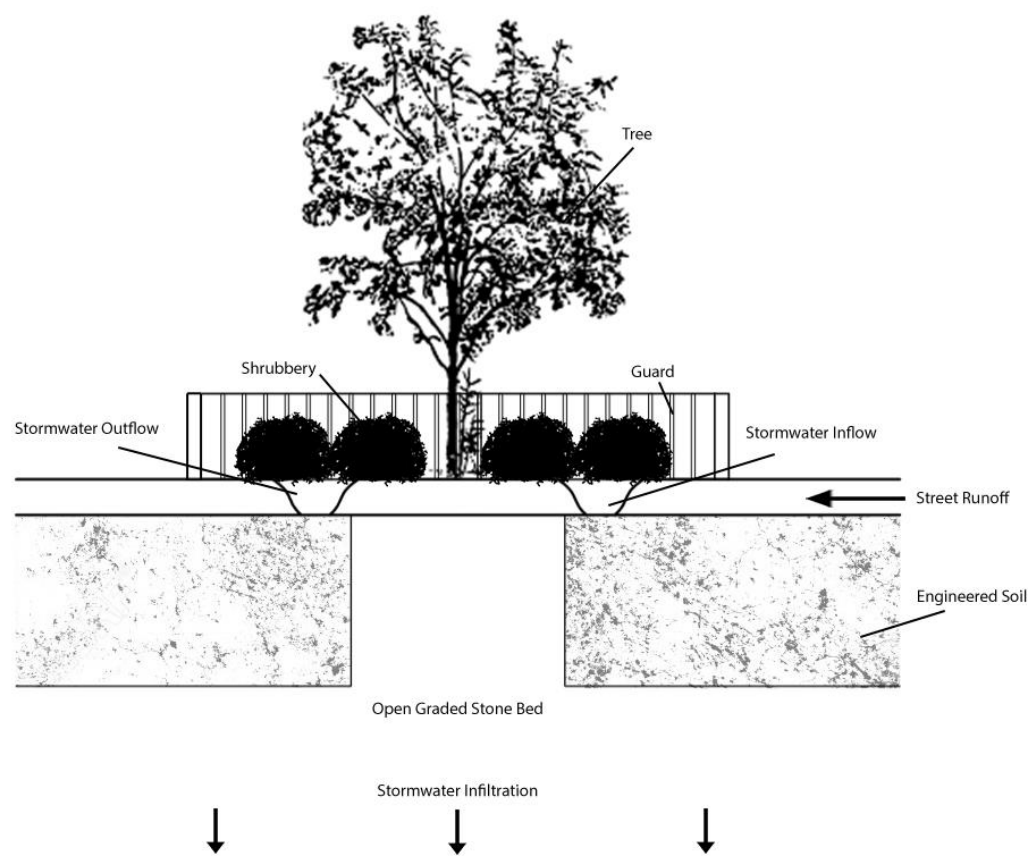

Figure 1. Section of an Example of a "Rain Garden" Bioswale in New York City.

Source: Drawing by author on the basis of a drawing from NYC Water Staff. (2017, February 22). More Rain Gardens to Choose From. Medium. Retrieved from https://medium.com/nycwater/more-rain-gardens-to-choose-from$\underline{3797 \mathrm{dc} 107687}$

\section{Benefits and Design}

There are many advantages to integrating bioswales into the urban settings - such as improvement of water quality, flood mitigation, improvement of air quality, improvement of biodiversity, and even improvement of mental health (Everett et al., 2015). Bioswales allow for surface runoff to enter the ground in locations that would otherwise be covered by elements like 
asphalt and cement. This allows bioswale to prevent the would-be runoff at the site, preventing a large volume accumulation of both runoff and particulate pollutants (McLaughlin, 2012). Particularly, if the bioswale is planted, the vegetation may also improve local air quality and provide some habitat for wildlife. In addition, the vegetation in the bioswales break up the monotony of urban settlements and brings in small patches of greenery that may contribute to improving human mental health (Pataki et al., 2011).

Spearheading a bold move towards green infrastructure, the New York City Department of Environmental Protection (NYCDEP) launched its bioswale program in 2010. New York City is in direct contact with many bodies of water, whether it be the Hudson River, East River, the Upper and Lower Bays, or the Atlantic Ocean (Sapienza, 2017). Therefore, any untreated water outflow from the city has an immense impact on the surrounding watershed. The usage of bioswales, or colloquially, what the NYCDEP calls "rain gardens," is a step in mitigating the overflowing of conventional wastewater treatment plants during heavy rainfall (Figure 2). The goal of bioswales in NYC is to be able to prevent 1.67 billion gallons of stormwater per year from running into the conventional water treatment systems in the city by 2030 (Sapienza, 2017). These rain gardens will move the city closer to this goal but cannot be solely relied upon to achieve this objective.

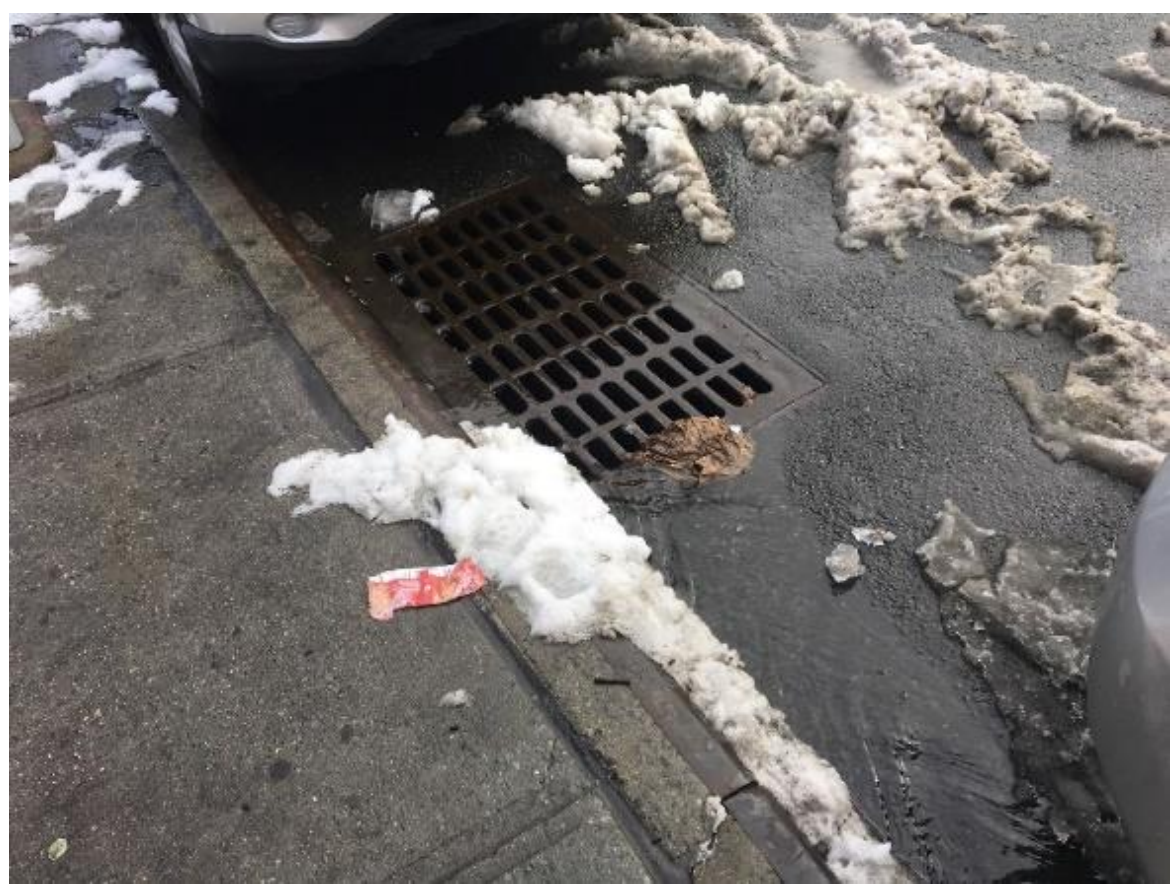

Figure 2. New York City Street Runoff from Melting Snow Entering the Drainage System. Source: Photograph by author, Flushing, New York, 2019. 
The rain gardens are basins integrated into the side of the street within the curb (Figure 3). As stormwater flows down the street, the rain garden catches the runoff through a depressed inlet area on the curb. Within the rain garden are layers of soil and vegetation. The water is then absorbed into these layers. If there is too much water, there is another depression in the curb that serves as an outlet. In the rain gardens, soils with high sand content are used in order to provide the highest degree of permeability that can be achieved (McLaughlin, 2012). New York City's rain gardens are an example of how bioswales can be integrated into metropolitan areas and are emulated in many cities across the United States.

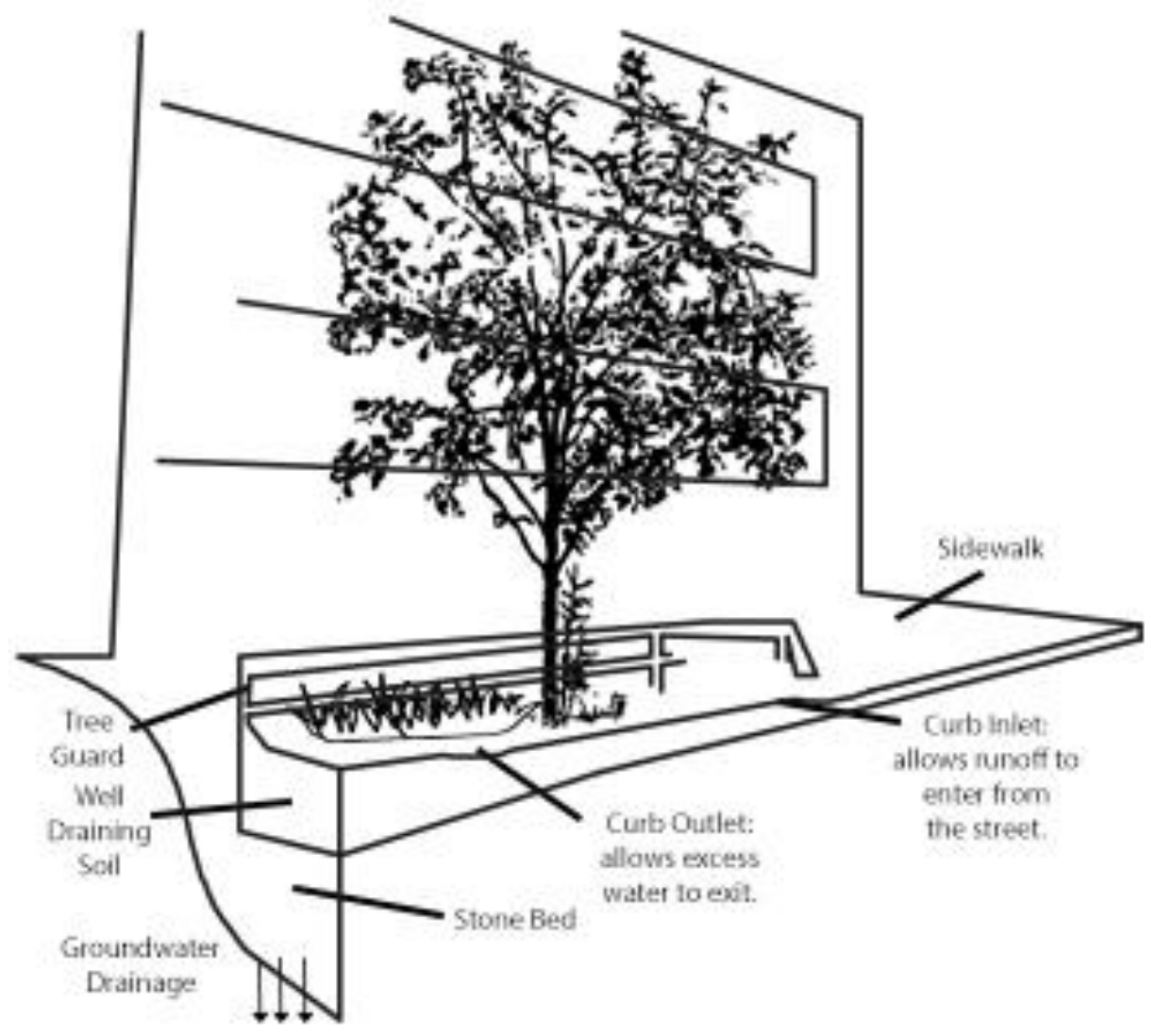

Figure 3. Design of the Rain Gardens of New York City.

Source: Drawing by author on the basis of a drawing from McLaughlin, J. (2012). NYC Bioswales Pilot Project Improves Stormwater Management. Clear Waters, 12(2), 20-23.

As mentioned before, urban population tend to suffer from air pollution and decline in visual aesthetic. In this regard, rain gardens are intended to not only assuage pressure from water drainage facilities but also promise to improve air quality and bring beauty to the localities in which they are constructed. NYC's rain gardens integrate some crucial foliage to the urban landscape (Figure 4). 


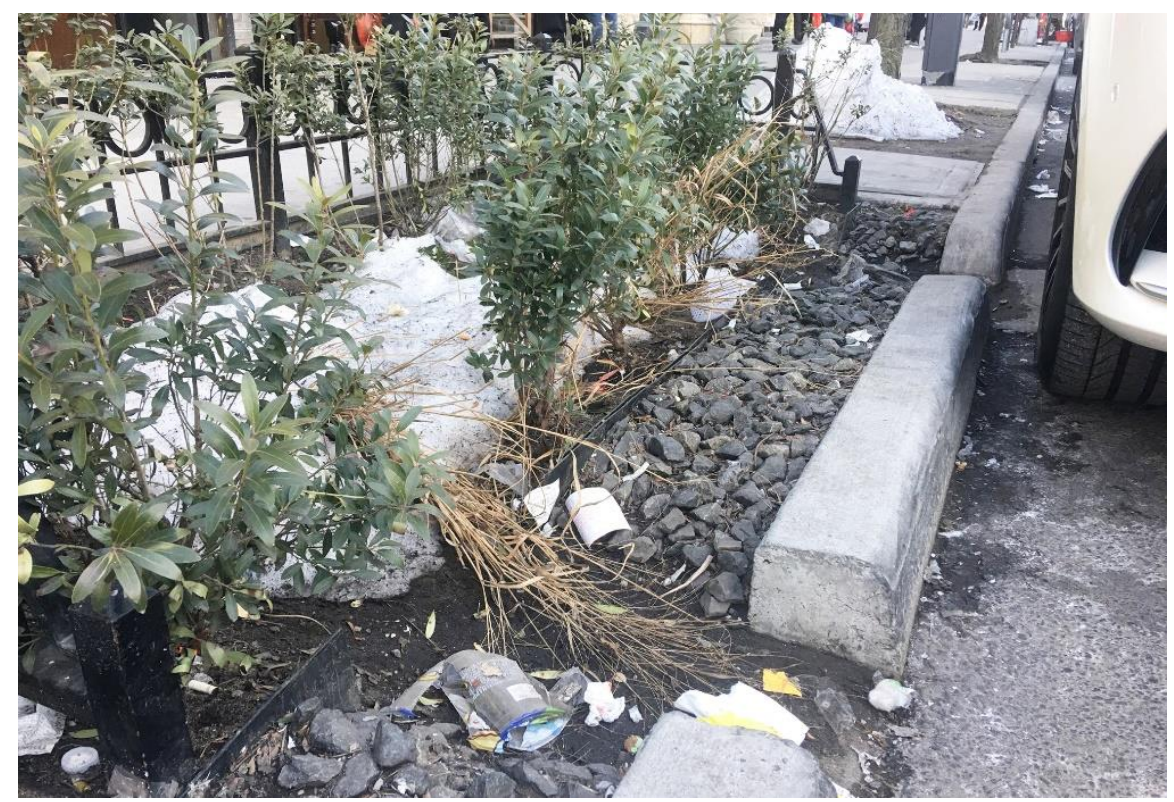

Figure 4. A Rain Garden in New York City's Queens Borough.

Source: Photograph by author, Flushing, New York, 2019.

\section{Water Quality Studies}

For the rain gardens, studies have concluded that they relieve conventional water drainage systems regardless of the amount of rainfall, however, bioswales are more effective when rainfall is lighter (McLaughlin, 2012). When rainfall is below one inch, the rain gardens collect an average of $73 \%$ of the rainfall, however, that number declines steeply as rainfall approaches two inches and above two inches of rain, the number drops to a $14 \%$ rainfall capture rate (McLaughlin, 2012). The significant decrease may be due to the limited surface area. Increased water flow into the rain garden may not have enough time to penetrate the surface of the rain garden, especially if the garden is already saturated. The capability of NYC's rain gardens appears to be inadequate for heavier rainfall, but there is no question that they bring much needed relief to conventional water management practices.

\section{Created Wetlands}

\section{Damages to the Coast}

With human affinity for the coast, first for trade and survival, but in modern times, also for the simple luxury of coastal living, our coastlines have been ecologically devastating. Because of this, wetland ecosystems, naturally biodiverse and ecologically important, have been destroyed by development. 
Wetlands are extremely valuable ecosystems that provide multiple services to the environment. Wetlands provide habitat for wildlife, have educational value, provide a catalyst for natural cycles, reduce water flow, filter the groundwater, retain particulate pollutants (such as heavy metals, lawn fertilizer, and excess nutrients), and prevent erosion (Donald, 2001). Without wetlands, natural water sources may lose ecological processes that provide vital restorative filtration. In the absence of the service provided by wetlands sediments, excessive nutrients like phosphate and nitrogen would flow freely without any limitations (Donald, 2001).

In attempt to resolve some of the issues that come with a lack of wetlands, created wetlands provide a quasi-natural means of retaining and filtering water inflow. Created wetlands are constructed counterparts to natural wetlands, often built in locations where wetlands used to exist but were removed due to development. Alternatively, they can also be created to supplement existing, naturally occurring wetland ecosystems.

\section{Benefits}

Created wetlands are multi-purpose green infrastructure facilities that also provide habitat restoration. "Wetlands" is the generic term that includes marshes, swamps, and bogs, which usually occur in low-lying land, along rivers, lakes, and coastal waters where they are subject to flooding (Tiner Jr. \& Fish and Wildlife Service, 1984). Wetlands occupy the territory between dry land that humans use for building cities and clearly defined water bodies such as rivers (Tiner Jr. \& Fish and Wildlife Service, 1984). Wetlands are one of the most valuable ecosystems and their advantages include biodiversity support, flood mitigation, and reduction of harmful water nutrient loads (Costanza, R. et.al., 1997). They can be used for building a natural system that distills both rainfall and groundwater through natural processes. These processes may include rainwater filtration through sediment and natural groundwater filtration. Pollutants like organic materials, excess nutrients, pathogens, and even heavy metals can be filtered out with a system of saturated substrate, vegetation, and animal life (Patel \& Dharaiya 2013). Created wetlands are an example of how humans can harness natural processes to enhance the environment and reduce the harmful impact of human development.

\section{Site Selection}

Created wetlands are most suited for areas that have suffered the greatest amount of wetland depletion in terms of both surface area and ecological functions (Kentula et al., 1993). When planning a created wetland, one of the first considerations is whether the wetlands should be 
supplied by surface or groundwater. Surface water focused wetlands hold rainwater like a bowl, relying on the presence of clay or silt to hold the water, while groundwater-based wetlands act like wells, holding the water underground (Kentula et al., 1993). Wetlands need silt or clay soils, thus an important criteria in the selection of a site is the presence of silt or clay soils (Biebighauser, 2007). Location is imperative for created wetlands because a wetland on a site that cannot function as wetland could lead to a facility that fails to hold water (Donald 2001).

\section{Freedom Park}

Freedom Park is a fifty-acre stormwater quality improvement facility in the Gordon River watershed in Naples, Florida. Freedom Park was developed to mitigate the damage that extensive waterfront development has caused in the Naples Bay watershed. Developmental strategies like the ecologically devastating "cut and fill” channels hold little regard for ecology (Dellapenna et al., 2015). Human induced processes have been destroying the former natural landscape and damaging time-tested ecological processes that keep the watershed healthy. Freedom Park utilizes created wetlands to restore numerous ecological functions including but not limited to rejuvenating some of the native habitat, stormwater filtration, and stormwater management (Bays \& Bishop, 2014).

\section{Anthropogenic Change}

Much of the problem comes from the conversion of natural estuaries and their systems into manmade replacements that have no resemblance to natural waterways. Some examples of this are shoreline altercations and canal systems that often connect previously unconnected drainage basins, consequently expanding the watershed. Not only does the construction destroy habitat and add considerable amounts of debris and waste into the water, in addition, expanded watershed leads to the cross contamination of pollutants and the expedition of the spread of pollution as natural barriers between ecosystems are removed. Development in areas that are naturally composed of wet soils generally may not be advised, as the soil may cause failures in infrastructure such as septic systems, which would directly discharge waste into the environment. In areas that are already low lying such as shorelines and riverbeds, runoff already naturally flows into these areas, and an increase in impervious surfaces from waterfront development only exacerbates the problem (Pover).

In 1926, with the completion of the Tamiami Trail, which connected Tampa, Naples, and Miami, waterfront property demand exploded. This led to great changes to the original mangrove 
and oyster-reef lined shores, which were often replaced by concrete seawalls (Dellapenna et al., 2015). Extensive systems of seagrass beds that aided in preventing erosion also existed before South Florida was extensively developed. The dislodging of the mangroves, seagrass beds, and oyster-reefs that kept the environment in balance had led to sand and mud dominated sediment. Increased sediment impacts ecology negatively, as it reduces the number of aquatic species and their productivity (Benedict \& McMahon, 2006). This type of sediment exacerbates erosion and increases turbidity, as sand and mud do not settle as readily as heavier sediments (Dellapenna et al., 2015). Freedom Park, a created wetland, was built to mitigate the anthropogenic impact on the watershed.

Naples Bay is a host for wildlife habitats and provides a buffer between saltwater and freshwater systems. It also provides natural water retention and filtration. A poignant point of concern is that due to the highly urbanized watershed, immense amounts of direct drainage enters the river and estuary. The creation of highly impermeable surfaces like roads, pavements, hard landscaped plazas, and buildings leads to a reduction of naturally permeable surfaces through which rainwater may drain into the ground. This forces water to drain into the river and bay, as municipal drainage and sewer systems often discharge directly into the natural waterways. Untreated discharge often leads to eutrophication. The increased presence of urban pollutants including fertilizer runoff and particulate matter from automobile exhaust further increases the pollutant levels in the runoff. In Naples, the Gordon River Master Plan was developed in 2002 to address these issues. Design on the Freedom Park project began in June 2005, and its construction began in December 2007 (Bishop, et al., 2012). Though born out of necessity in the face of ecological devastation, Freedom Park inaugurated an initiative to protect the Naples Bay watershed

\section{The Design}

Freedom Park demonstrates how using plants and natural ecological processes can be integrated into water treatment facilities. Broken down to the two main components, the treatment system uses a pond and native herbaceous wetlands (Figure 5).

Within Freedom Park, the integrated pond is used for stormwater storage. The pond slowly allows water to enter the created wetlands. As rainfall occurs, the runoff is directed into the pond for initial storage. The series of constructed marshes after the pond are designed to remove harmful pollutants from the stormwater before the water is released into the watershed (Figure 
6). The system of marshes is composed of both shallow and deep elements. The shallow marshes, which are no deeper than about 30 centimeters $(\mathrm{cm})$, are home to native emergent plants, such as picker weed, spike rush, sawgrass, duck-potato, and fire flag (Figure 7) (Bishop, et al., 2012). The deeper marshes, that may be as deep as $130 \mathrm{~cm}$, include water lily, spatterdock, and other species of submerged vegetation (Vasquez-Burney, 2016). Much consideration was put into the selection of native vegetation. By utilizing native plants, the efficiency of this system increases significantly due to the ability of the plants to thrive and adapt to a familiar climate.

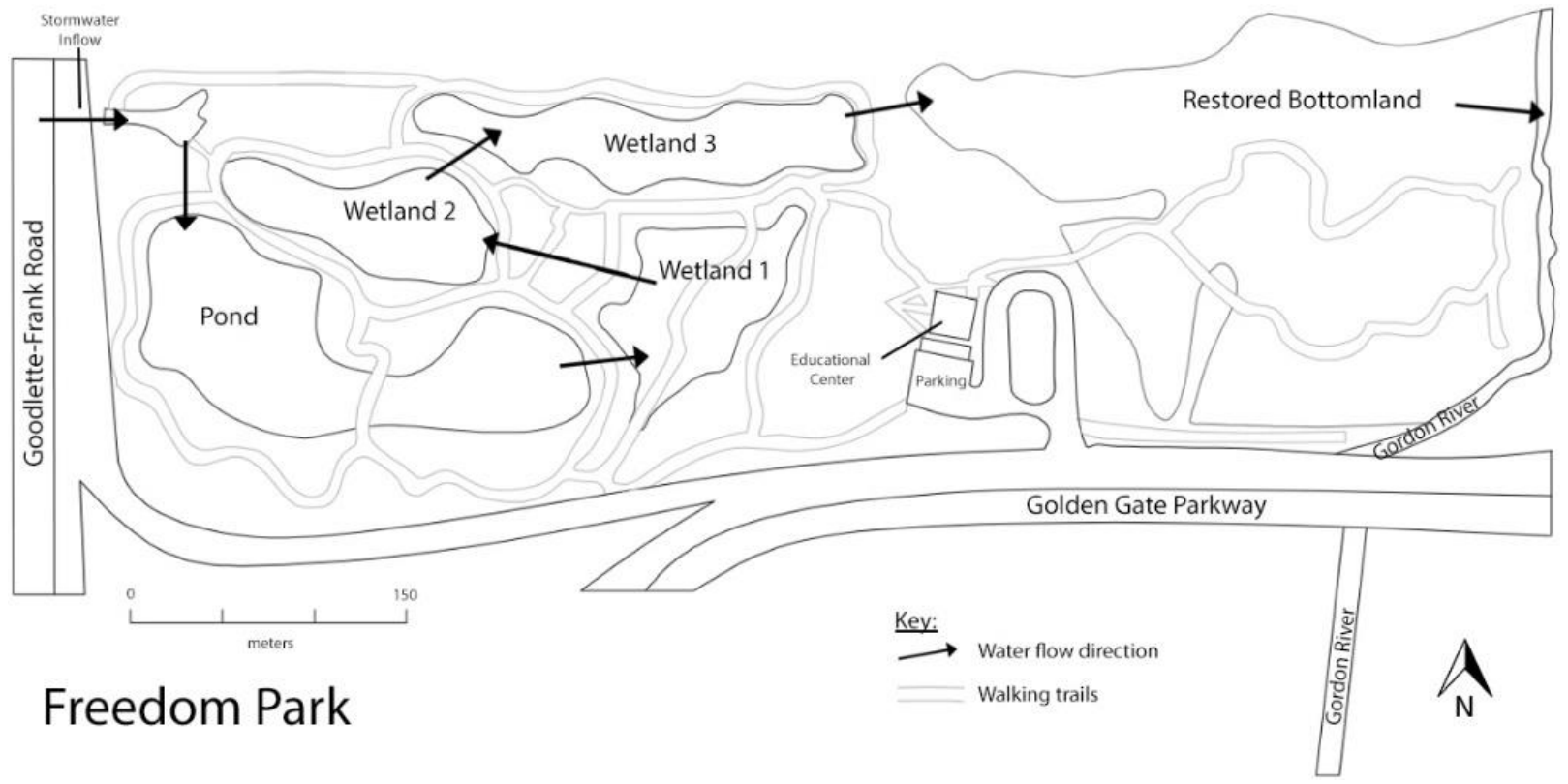

Figure 5. Drawing Depicting a Birds-eye of Freedom Park, Naples FL

Source: Drawing by author on the basis of a drawing of the plan of Freedom Park from Bishop, M., Bays, J., Griffin, M., \& Gramer, W. (2012). More Than a Pretty Space: Stormwater Treatment Wetlands with Multiple Benefits at Freedom Park, Naples FL. In Proceedings of the 85th Annual conference of the Water Environment Federation (pp. 8094-8115). Alexandria, Virginia: Water Environment Federation. 


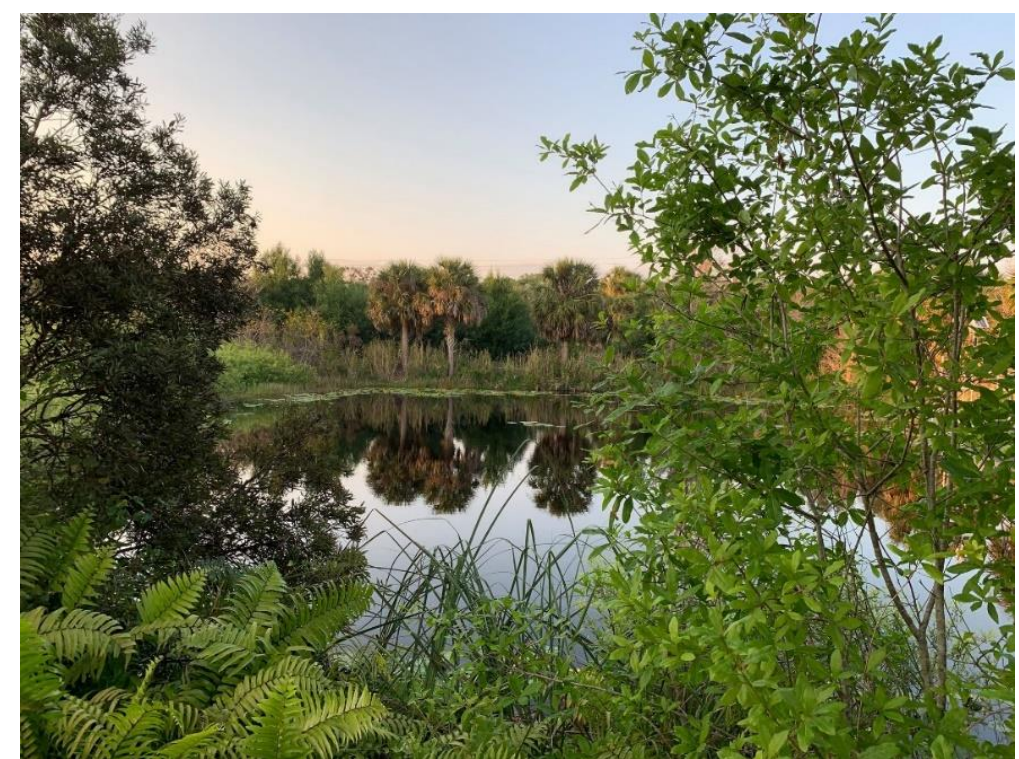

Figure 6. Photograph of the Pond in Freedom Park Source: Photograph by author, Naples. Florida, 2019.

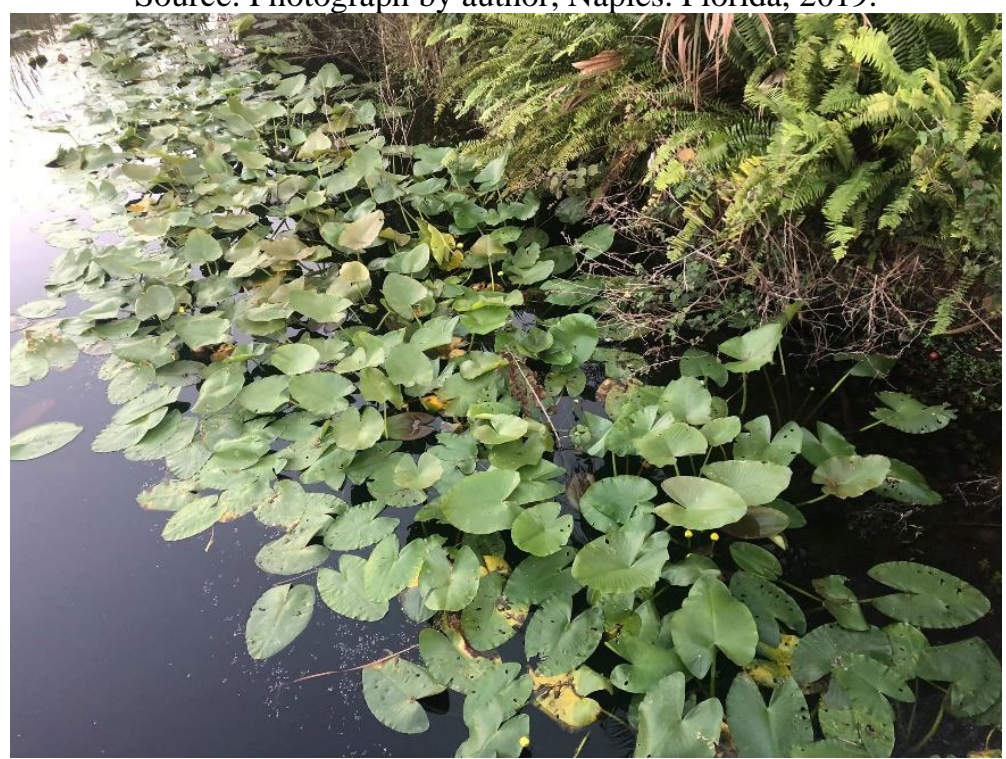

Figure 7. Photograph of Emergent Vegetation in Freedom Park Source: Photograph by author, Naples, Florida, 2019.

\section{Water Quality Studies}

Freedom Park discharges into the neighboring Gordon River, which was highly polluted due to harmful direct discharge before the creation of the wetlands. Phosphorus and nitrogen, while essential for life, are harmful to water bodies in excessive amounts. Excess nitrogen and phosphorus in water bodies can cause eutrophication. Because of eutrophication, other forms of life, like fish, may either be forced out of the area or simply perish, and excessive growth of plants may obstruct waterways in both natural and manmade systems, such as congesting pipes. 
Excessive nutrients mainly come from agricultural runoff, though runoff from urban centers also contributes to the problem.

The creation of Freedom Park has significantly reduced the nutrient load on the water being discharged into the Gordon River. This is evident through a reduction in Phosphorus and Nitrogen levels. Between January 2008 and November 2011, the median inflow amount of Phosphorus in the water that initially entered the wetland was $0.196 \mathrm{mg} / \mathrm{L}$, while the median outflow amount of Phosphorus from the wetlands was $0.032 \mathrm{mg} / \mathrm{L}$ (Bishop, et al., 2012). This is a decrease of $84 \%$ in Phosphorus concentration between the water that flows into the manmade wetlands and the water that discharges from the green infrastructure into the neighboring Gordon River.

When looking at Nitrogen amounts in the water moving through the wetland, from the same time period, median inflow amounts of Nitrogen were $1.38 \mathrm{mg} / \mathrm{L}$ while median outflow amounts of Nitrogen in the water was at $0.87 \mathrm{mg} / \mathrm{L}$ (Bishop, et al., 2012). This is a decrease of $37 \%$ in median Nitrogen content in the water that passed through the created wetland. These numbers were an important indication that the wetlands were functioning as planned. The park has an undeniable impact on the quality of water entering the Gordon River, which in turn provides much of the region with fresh water.

\section{Habitat Restoration}

While water filtration is one of the main focuses of Freedom Park's manmade wetlands, habitat restoration is another focus. Freedom Park aimed to restore 12.5 acres of habitat through the targeted removal of nonnative plants such as melaleuca trees and Brazilian pepper (VazquezBurney, R., 2016). Great care was taken to only remove non-native and invasive species while keeping native plants intact. Over half the canopy was removed in order to provide an opportunity for native species such as the Florida royal palm, flowering pickerelweed and swamp lily. As the old canopy cover was removed, native plant species were planted to restore the ecosystem. By the third year, median ground cover had increased from $37 \%$ to $76 \%$, a testimony to the success that native species flourished after removal of the taller nonnative plants (Bays \& Bishop, 2014). Without foreign flora, native plants could rejuvenate the previously impaired ecosystem. 


\section{Conclusion}

Throughout history, humans have increasingly degraded the environment. Increased rates of water pollution, rainwater runoff, eutrophication, particulate pollutants, habitat loss, and air quality degradation are few of the many issues caused by unplanned urbanization. When faced with the issue of decades of unhindered, exponential urban growth, researchers, at first, may scramble for solutions.

Green infrastructure seems to be an important tool for urban planners. By reducing the velocity and amount of rainwater runoff, reducing the amount of particulate matter, mitigating erosion and habitat loss, green infrastructure restores some of the health to ecosystems that would otherwise be devastated by unchecked urban development.

The New York City's "rain garden" bioswales project show how green infrastructure can be successfully installed in large metropolitan areas. It is a successful model for urban planners to follow when it comes to drainage alternatives and/or supplements. On the other hand, the created wetlands of Freedom Park are a successful case in areas where land is plentiful and suited for wetlands. The park has proven its efficacy not only via water filtration but also through successful habitat restoration with native fauna and flora. When looking for successful examples of green infrastructure, one could look no further than the bioswales of New York City and the created wetlands of Freedom Park. Green infrastructure, as seen through these two case studies have shown that the idea is viable and will benefit the landscape surrounding urban development.

\section{Acknowledgments}

I would like to thank my mentors for their high degree of academic rigor and their guidance throughout the process of writing this paper.

\section{References}

Bays, J. S., \& Bishop, M. (2014). Meeting Multiple Objectives in Stormwater Treatment at Freedom Park. Florida Water Resources Journal, 66(7), 46-52.

Benedict, M. A., \& McMahon, E. (2006). Green infrastructure: linking landscapes and communities. Washington, DC: Island Press.

Biebighauser, T. R. (2007). Wetland drainage, restoration, and repair. Lexington: The University Press of Kentucky. 
Bishop, M., Bays, J., Griffin, M., \& Gramer, W. (2012). More Than a Pretty Space: Stormwater Treatment Wetlands with Multiple Benefits at Freedom Park, Naples FL. In Proceedings of the 85th Annual conference of the Water Environment Federation (pp. 8094-8115). Alexandria, Virginia: Water Environment Federation.

Collier County. (n.d.). Freedom Park | Collier County, FL. Retrieved March 21, 2019, from https://www.colliercountyfl.gov/your-government/divisions-a-e/conservation-collier/preserveinformation/freedom-park

Communication from The Commission to The European Parliament, The Council, The European Economic and Social Committee and The Committee of The Regions. (2013). Green Infrastructure (GI) - Enhancing Europe's Natural Capital (No. Document 52013DC0249). European Commission. Retrieved from https://eur-lex.europa.eu/legalcontent/EN/ALL/?uri=celex:52013DC0249

Costanza, R., d'Arge, R., de Groot, R., Farber, S., Grasso, M., Hannah, B., Limburg, K., Naeem, S., O’Neill, R.V., Paruelo, J., Raskin, R.G., Sutton, P., van den Belt, M. (1997). The Value of the World's Ecosystem Services and Natural Capital. Nature, 387(6630), 253-260.

Dellapenna, T. M., Fielder, B., Noll, C. J., \& Savarese, M. (2013). Geological Responses to Urbanization of the Naples Bay Estuarine System, Southwestern Florida, USA. Estuaries and Coasts, 38(Suppl 1), S81-S96.

Donald, K. M. (2001). Evaluating Wetland Functions and Values. In Applied Wetlands Science and Technology (Second Edition, pp. 55-80). Boca Raton, Florida: CRC Press LLC.

Environmental Protection Agency. (2011). Land Revitalization Fact Sheet: Green Infrastructure (No. EPA 560-F-11-007). Retrieved from https://www.epa.gov/sites/production/files/2014-

07/documents/fs_green_infrastructure.pdf

Everett, G., Lamond, J. E., Morzillo, A. T., Matsler, A. M., \& Chan, F. K. S. (2018). Delivering Green Streets: an exploration of changing perceptions and behaviours over time around bioswales in Portland, Oregon. Journal of Flood Risk Management, 11(S2), S973-S985.

Firehock, K. (2010). A Short History of the Term Green Infrastructure and Selected Literature. Green Infrastructure Center. Retrieved from http://www.gicinc.org/PDFs/GI\%20History.pdf

Florida Greenways Commission, MacKay, B., \& Reed., N. P. (1994). Creating a Statewide Greenways System. Tallahassee. Retrieved from https://floridadep.gov/sites/default/files/1994FloridaGreenwaysCommissionPlan.pdf

Grenz, N. (2007). Efficiency of Bioswales in Positively Affecting Storm Water Quality (Honors Baccalaureate). Oregon State University, Oregon. Retrieved from https://ir.library.oregonstate.edu/downloads/79408012f?locale=en

Groves, W. W., Hammer, P. E., Knutsen, K., Ryan, S., \& Schlipf, R. (1999). Analysis of Bioswale Efficiency for Treating Surface Runoff (A Group Project submitted in partial satisfaction of the requirements of the degree Master of Environmental Science and Management). University of California, Santa Barbara. Retrieved from http://www.bren.ucsb.edu/research/finaldocs/1999/bioswale.pdf 
Hawkins, N. C., \& Pricket, G. (2014). The case for green infrastructure. In R. Kupers (Ed.), Turbulence: A Corporate Perspective on Collaborating for Resilience (pp. 87-100). Amsterdam: Amsterdam University Press.

Karolina, R. (2018). ArcGIS - DEP Green Infrastructure Program Map. Retrieved from http://www.arcgis.com/home/webmap/viewer.html?webmap=a3763a30d4ae459199dd01d4521d993 9\&extent=-74.3899,40.497,-73.3757,40.9523

Kentula, M. E., \& Hairston, A. J. (2018). An approach to improving decision making in wetland restoration and creation. Boca Raton, Florida: CRC Press.

Lovell, S. T., \& Johnston, D. M. (2009). Designing Landscapes for Performance Based on Emerging Principles in Landscape Ecology. Ecology and Society, 14(1), 44.

McLaughlin, J. (2012). NYC Bioswales Pilot Project Improves Stormwater Management. Clear Waters, 12(2), 20-23.

Mejía, C. V., Shirotova, L., \& de Almeida, I. F. M. (2015). Green Infrastructure and German Landscape Planning: A Comparison of Approaches. Urbani Izziv, 26(Supplement), S25-37.

NYC Water Staff. (2017, February 22). More Rain Gardens to Choose From. Medium. Retrieved from https://medium.com/nycwater/more-rain-gardens-to-choose-from-3797dc107687

Pataki, D. E., Carreiro, M. M., Cherrier, J., Grulke, N. E., Jennings, V., Pincetl, S., Pouyat, R., Whitlow, T. H., Zipperer, W. C. (2011). Coupling biogeochemical cycles in urban environments: Ecosystem services, green solutions, and misconceptions. Frontiers in Ecology and the Environment, 9(1), 2736.

Patel, P. A., \& Dharaiya, N. A. (2013). Manmade Wetland for Wastewater Treatment with Special Emphasis on Design Criteria. Scientific Reviews \& Chemical Communications, 3(3), 150-160.

Poyer, Denise. Unit VI: Effects of Land Use on the Watershed [PDF]. Retrieved from https://web.uri.edu/riss/files/EffectsofLandUseonWatershed.pdf

Sapienza, V. (2017). NYC Green Infrastructure (Annual Report) (pp. 1-51). New York City: NYC Department of Environmental Protection. Retrieved from https://www1.nyc.gov/html/dep/pdf/green_infrastructure/gi_annual_report_2018.pdf

Soil Science Society of America. Mimicking the Soil with Green Infrastructure. Retrieved June 15, 2019, from https://www.soils.org/discover-soils/soils-in-the-city/green-infrastructure/building-greeninfrastructure

Tiner Jr, R. W., \& Fish and Wildlife Service. (1984). Wetlands of the United States: Current Status and Recent Trends. Newton Corner, Massachusetts: U.S. Department of the Interior. Retrieved from https://www.fwspubs.org/doi/suppl/10.3996/092015-JFWM-085/suppl file/092015-jfwm085.s7.pdf

Vazquez-Burney, R. (2016, November). Comprehensive Watershed Improvement Program (CWIP). Presented at the Technical Advisory Ad Hoc Committee Meeting, Naples, Florida. Retrieved from https://www.colliercountyfl.gov/home/showdocument?id=69987 
Xiao, Q., Zhang, Q., Dahlgren, R., McPherson, E., \& Ge, X. (2017). Performance of Two Bioswales on Urban Runoff Management. Infrastructures, 2(12), 1-14. 